\title{
BATIK WASTEWATER MANAGEMENT ANALYSIS BY INTEGRATED COMUNAL, CASE STUDY OF KAMPOENG BATIK LAWEYAN
}

\author{
Ravita Sari $^{1}$, Tri Edhi Budhi Soesilo ${ }^{2}$, Herdis Herdiansyah ${ }^{3 *}$ \\ .*E-mail:herdis@ui.ac.id
}

\begin{abstract}
Batik industry is one of the industries that produces wastewater which contains harmful chemicals. In order to maintain the quality of the environment, it is necessary to have a wastewater management system. The region which has conducted the comunal waste management system is Kampoeng Batik Laweyan. However, this effort of waste management system has not optimal yet. The purpose of this paper is to analyze wastewater management system in Kampoeng Batik Laweyan. The approach of this paper is a quantitative approach, using mix-metode. The analysis of the wastewater management system has been done by assesing 4 aspects such as technical aspect, managerial aspect, economic aspect, and environmental aspect. The wastewater management system has provided good results in technical dan managerial aspects only. For the economic and the environment aspects need to be upgraded since they have not shown any important improvements. Through this paper it is expected to create a substantial improvement in economic and environmental aspects.

Keyword: Batik waste, Laweyan, management, wastewater, WWTP.
\end{abstract}

\section{INTRODUCTION}

In year 2012, batik industry in Surakarta had $529.216,43 \mathrm{~kg}$ export value with the value price US \$ 10,473,535.70. In 2013 the export value increased to $609.662,49 \mathrm{~kg}$ with the value of the item price US \$ 12,317,114.86 (Alhusain, 2015:207). The existency of this batik industry had provided positive impacts for laweyan community such as the increase of the employment factor in this batik industry and improvement of the economic sectors such as trades and services (Wihastoro, 2013:132). The development of batik industry not only offers a positive impact, but also a negative impact. One of the 
negative impacts from this industry is the wastewater from washing and dyening processes.

Wastewater of batik industrial is very dangerous, because they contain chemicals which are harmful to the environment. The Batik industrial wastes contribute harmful results in organic matter contents, suspended solids, oil or grease, and content of dangerous heavy metals such as $\mathrm{Zn}, \mathrm{Cd}, \mathrm{Cu}$, $\mathrm{Cr}$ and $\mathrm{Pb}$ (Nurdalia, 2006:108). Batik wastewater that is streamed directly into water will lead to decrease the quality of the environment. If this wastewater standard is higher than the quality standards, it will lead to the death of aquatic organisms (Al-Kdasi, 2004:222). To minimize the impact, the waste management system should be provided. This effort can be conducted by using the Waste Water Treatment Plant (WWTP). The implementation of WWTP in Kampoeng Batik Laweyan has been running since year 2008 but only 6 industries had joined this communal WWTP. Industries that join with this implementation are Batik Gress Tenan, Batik Putra Laweyan, Batik Mahkota Laweyan, Batik Gunawan Design, Batik Puspa Kencana, Batik Cempaka, Batik Surya Pelangi and Batik Adina (Priyatmono, 2014:1-5).

The implementation of this management system had some problems at that time. Those problems related to the implementation of this WWTP included the pipe of wastewater was not functioning optimally, there were some strong stink odor, and the availability of cost. To manage this environmental management needs the sustainable approach in wastewater management, and this sustainable approach should be economically affordable, socially acceptable and environmentally effective (McDougall, 2007:3; Tortajada, 2003:124). The method is done by decreasing the amount of waste that produced, and developed the Integrated Waste Management system to handle waste (McDougall, 2007:8). The waste management only focused on aspects of economic, physical and environment, by considering the wastewater treatment methods and the results of waste quality standards, without taking consider the social aspects $(\mathrm{Lu}, 2016: 1$; Bratina et al, 2016:1014; Sun et al, 2016:4; Piao, 2015 :326; Legras, 2015:83).

Waste management system not only require an assessment of technical and economic aspects alone, but also requires an assessment of the social / institutional and environmental (Agamuthu, 2007:17; Hellstrom, 2000:315, Tsagarakis, 2001:173). 
The susainable of wastewater management system have some focus such as the user opinion, the level of service, economy, performance, materials, personnel, equipment, and labor control (WHO, 2000:19). Management aspects are needed for social organization, social acceptance, and workers. The assesment of this aspect is important because the management effort can not walk alone, but it requires organizations and workers who run it. This management will be sustainable if the organization is conducted well, because the waste management can not be run only by focusing on the treatment process alone.

The purpose of this paper is to evaluate the batik wastewater management system which has been done by Kampoeng Batik Laweyan community. The evaluation is conducted by assessing the aspects which existed in the waste management system , such as technical, organizational (managerial), economy, and environment factors. This paper is expected to be an alternative in an effort to improve the managerial system in order to make it will be more sustainable in the future.

\section{MATERIALS AND METHODS}

This study was held in Kampoeng Batik Laweyan, Surakarta, Central Java. The reasons for selecting this location because
Kampoeng Laweyan Batik is one of the largest batik villages in Surakarta, therefore the amount of waste produced is in high level. In addition WWTP in Laweyan is a guidance of communal wastewater management batik in Surakarta. The approach is a quantitative approach with mix-method. The management processes studied in this paper is divided into four aspects: technical acpects, managerial aspects, economic aspects and environmental aspects (Hellstrom, 2000:315).

The technical aspect which was examined in the process of waste treatment included the monitoring efforts, and the implementation of the 3R's. The managerial aspects which were examined included the operator coordination and the knowledge of WWTP operator (Aspinwall, 1997:1443). For the economical aspect was assessed by comparing the income and the expenditure, for profit calculation (Helstrom, 2000:31). While the environmental aspect was assessed by measuring the quality of the wastewater after the treatment. Informan in this study are operator, former operational, and industrial who joined WWTP. Technical and managerial aspect using qualitative method, environmental and economic aspect using quantitative method.

\section{RESULTS AND DISCUSSIONS}




\section{The management of the technical aspect}

One of technical aspects was examined in used technologies (Aydiner, 2016:4605). Waste treatment method that we used today have shifted from processing into waste management in cleaner production (Aspinwall, 1997:1435). The technical aspects were studied in this paper are the process of waste treatment system, the monitoring effort, and the implementation of the $3 R$ 's.

" The waste treatment system consists of 5 stages of processing. The first stage is the removal of solid particles (wax) by flotation. Second stage is sedimentation, third stage is the treatment using bacteria. The fourth stage is stones filter. The last stage is the adsorption of the chemical component which contains coconut shell charcoal and stones. "

Theoretically the wastewater treatment, based on the process, the wastewater treatment has 3 treatment levels. The first level is primary treatment, secondary treatment and tertiary treatment (Metcalf and Eddy, 1991:125). Wastewater batik contains suspended solid, organic matter, and heavy metal, so that the level treatment must do primary, secondary, and tertiary treatment. Based on the interviews and observations, the processing treatment which has been carried out in Kampoeng

\section{a. Processing}

The wastewater treatment process in Kampoeng Batik Laweyan employs a natural way. The treatment process uses natural energy by utilizing the gravity force. The Processing wastewater system employs DEWATS system which means applying the decentralized wastewater treatment. The waste water treatment is done communally, by providing a management to an organization in Laweyan. From the interview with former operational WWTP officer.

Batik Laweyan had been through with an appropriate wastewater treatment stages in the sewage treatment theory. Preliminary stage treatment has been carried out in each of the industries which filtering wax, plastic, and fiber before it flows to WWTP. In the primary stage of treatment is done by using the equalization basin. The primary treatment will remove solid materials (wax). This stage occurs in the equalization basin, which process the flotation process. Wax that are still carried by wastewater in WWTP will be floated, so there is no impact to the WWTP process. The secondary treatment is sedimentation to reduce TSS and to reduce $\mathrm{pH}$. The fourth stage is the biological treatment process involving microorganisms (bacteria). In this stage, the treatment occurs in the second basin involving the help of the stones and the bacteria. The Tertiary treatment is decreasing the substances that 
still contained in the wastewater. At this The treatment process of wastewater batik in stage the treatment process using activated Kampoeng Batik Laweyan can be seen in carbon that is using coconut shell charcoal.

Figure 1.

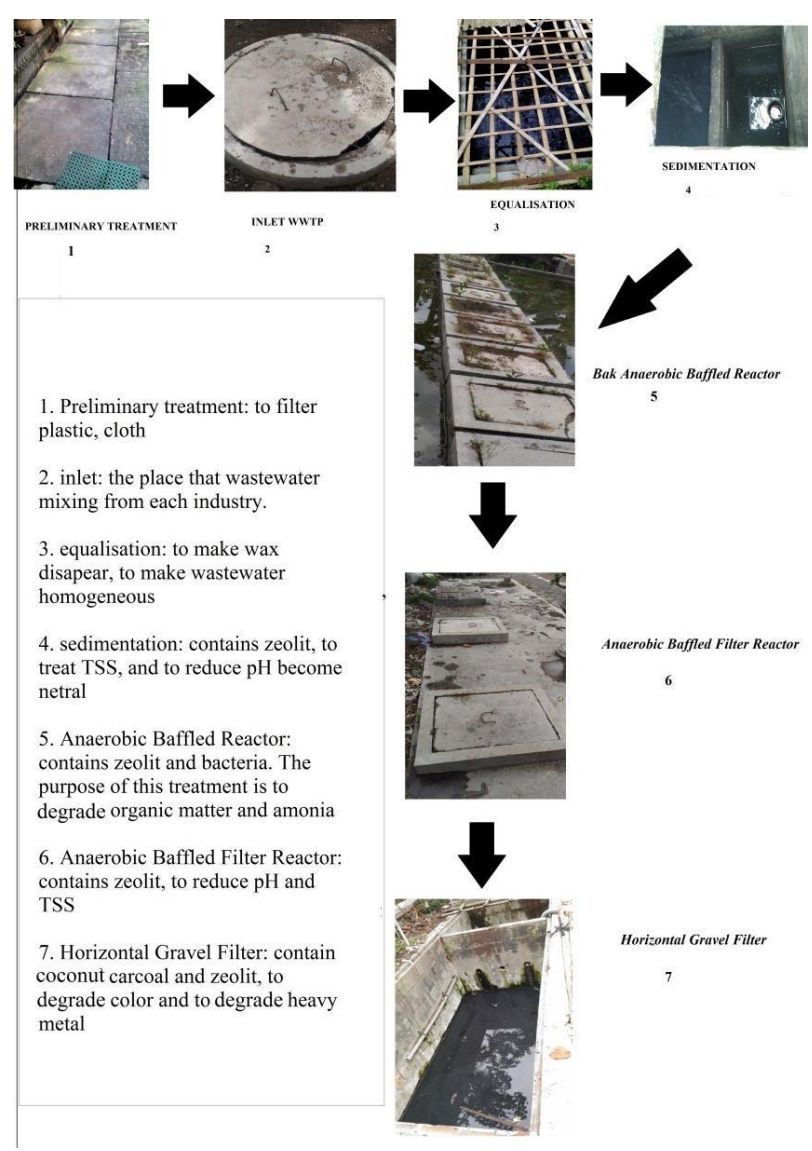

Figure 1. Wastewater treatment process in Kampoeng Batik Laweyan

\section{b. Supervision}

This process is to determine whether the processing operation is running well or not. By applying the surveillanve earlier, the damage will be quick monitored to anticipate that a big impact not produced. (Rivera, 2016:104). The control process WWTP is usually the task of the operator. In the wastewater treatment activities of Kampoeng Batik Laweyan, the operator does not do the routine supervision. The operator usually only observes occasionally the waste treatment process. This occasionally supervision can rise the risks of damage becomes larger. The operator will know about the process is not going well when the impact has occured. For example, the operator will take into action if there are some reports about the damage or blockage of the waste water flow. The operator will notice the wastewater irregularity when the 
wastewater has been overflowed into the road. Currently the Supervision of this activity has not been conducted improperly. The operator has only conducted routine activity to clean up the stone and coconut shell charcoal or repaired the damages.

\section{c. The 3R's (reduce, reuse, recycle)}

The efforts of waste management aim to minimize the waste stream by reducing, reusing, and recycling. These efforts are made to minimizing the waste, and they also can generate the increasing income (Aspinwall, 1997:1431; Gray, 1997:78). The $3 \mathrm{R}$ efforts to reduce the amount and content of wastewater is done by using of dyes, wax and water use.

\section{- $\quad$ Dye Process}

Dyeing process in Laweyan Kampoeng Batik industry employs indigozol, naptol, and reactive (remasol). Almost all of the industry owners will not dispose the waste residual of the dye industry from the dyeing and penoletan process. This dye is used continuously for further production until it finished, as it is done in the Industry Gress Tenan.

According to interviewees, who joined the Communal WWTP "This type of batik dye used are naptol and remasol. The price of dye batik is expensive, so that dyes are used as efficiently as possible and remnant of the dye after the production process is not discarded but will be saved for reuse again."

In the penoletan process also occurred the same thing. Dyes will be put in space like cans, and this happened in batik Puspa Kencana. Dyes will be used continuously, if the dyes is not used then the dye will be stored and they will be used again if they are needed. Not only that, the industry also often mixes the former dyes which is not used for making the new other dye. They argued that the price of the dye was relatively expensive, so they were reluctant to discard it. Naptol in the market price can reach up to $\mathrm{Rp}$ $200,000.00 / \mathrm{kg}$, and the price for remasol Rp 100,000.00 until 150,000.00/kg.

They will use the dye until it has been used up or nothing left over. When the resulting color made starts fading, the workers will add a new dye which colors the remaining products until it produces the same colour as the previous production. From the amount of the dye, the industry has been using dyes with a minimum dose. This is because the price of the dye is so expensive. They consider that if they only use the dye once and dispose it directly, it will increase the production costs.

The use of natural dye batik is less 
enthushed to the batik employers. It is because of many ineficiency factors involved. The natural dye batik has a higher price than the sintetic dye, and coloring process is needed more time. The process of dyeing with natural dyes requires 5-20 times to get the color looks. This will require more power and more time. The replacement effort of the use of batik natural dye to the synthetic is still not reliable. Businessman would prefer to use synthetic dyes that only need 2 times5 times dyeing to get the colour look. On the other hand, synthetic dyes are more dangerous which offer a negative impact to the environment. The minimazing waste efforts used by the synthetic dyes can be achieved with a minimum dose. Although they can not replace the dye synthetic, they have reduced the waste water by minimizing the synthetic dye.

- The usage of wax

The efforts to minimize the use of wax made by recyle. The wax that dissolved with wastewater will be done the treatment. The wax of batik production will be collected and will be processed by heating process for reuse again. If the owner has not been able to do the processing wax, they will sell the wax of the production process to the wax collectors. The aim of this effort is to minimize the amount of wax is thrown away to the environment, and it can minimize the costs production and increase the profits.

- $\quad$ The usage of clean water

The Efforts to minimize the usage of the clean water is done by using a rolling system. This system is very helpful in saving water. The dishwater will be discarded if it is extremely dirty. The existing problems of the washing process are by using 3 washing tubs. The effort to reduce the number of washing tub is very difficult to be reduced. According to the perception of the owners of industry, the efforts to reduce the amount of water for the washing process will affect the quality of batik.

\section{The management of managerial aspects}

Theoretically, managerial aspects is important in terms of communication in which communicating what happened to the organization, also there is a report for each activity. This is done to achieve the sustainable management in order to reduce the impact on the environment (Aspinwall, 1997:1443)

According to the WWTP operator currently states that: "The process of the repairment and maintenance of communal WWTP is now being made by the former operational 
WWTP. I will only monitor of WWTP equipment and report the condition to the organization."

The operator of WWTP does not have the knowledge about WWTP treatment. The information about the WWTP and processing maintainance known only by the former operator of WWTP. In terms of the coordination, operator has a good coordination. Coordination is done by the manager of WWTP and the head of organization, and the person who will repair the WWTP. WWTP operational says that:

"Operator will make report the condition of the WWTP to the head of organization manager and head of WWTP manager, in the form of an oral report"

\section{Management of the economic aspects}

In the economic aspects carried out using the theory of profit, where any activity not to cause harm. Indicators studied is income, operational/ maintenance (Helstrom, 2000:317). The economic aspect studied is operating costs, and economic profit (Piao, 2016:320).

According to the former WWTP operator says that: "The operating costs derived from the contributions of each industries. Expenditure made for the salary payment to the operator, and purchase intake treatment facility. The contributions of each industry start from $\operatorname{Rp} 25,000.00$ to $\operatorname{Rp} 80,000$ 's. The cost to pay the cleaning workers is conducted every three months. It means, the cost of Rp 75,000 / person / day and the cleaning job is done for 3 days."

Income is derived from the contributions each of the industries that have joined the integrated WWTP. There are 6 industries that have been join such as Gress Tenan Industry, Mahkota, Adiyan, Cempaka, Gunawan Design, and Puspa Kencana Industry. The amount of monthly income is $\mathrm{Rp} 304,500.00$. The operational costs used for salary payment to the operator, purchase of pur and repair WWTP if the damage occurs. Of the total payments have been collected, the amount US \$300,000.00/month will be used for payment operator WWTP and US \$ $50,000.00 /$ month for the purchase of pur (see Table 1 Income and Expenditure in Waste Management Kampoeng Batik Laweyan). The purchase of this pur used to give nutrients to the bacteria in Buffle Reactor because the toilet used is not yet optimal. The Income received is less than the real expenditure, as a result a lack of fund.

That cost does not include for cleaning WWTP. The cost of maintenance 
is done every 3 months to clean WWTP equipment. This treatment is done in the efforts to wash the rock and charcoal of coconut shell, that does not need a lot of money. In the cleanup effort, the operator is helped by 2 people. Cleanup activities carried out for 2-3 days, a cost to pay workers Rp75,000.00 / person / day. If it is calculated for 3 days with two workers then the required cost as much as Rp300,000.00 for every 3 months for the cleaning process. From the amount of cash earned, it was not able to pay for the cleanup. This expenditure is not included the cost of damage.

Table 1

Income and Expenditure in Waste Management Kampoeng Batik Laweyan

\begin{tabular}{|c|c|c|c|c|c|}
\hline \multicolumn{3}{|c|}{ Income } & \multicolumn{3}{|c|}{ Ependiture } \\
\hline$\overline{\mathrm{N}}$ & Industry & Total & $\mathrm{N}$ & Type of & Total \\
\hline o & Contribution & (Rp) & o & expenditure & (Rp) \\
\hline 1 & Gress tenan & 70.000 & 1 & Salary operator & $\begin{array}{r}300.0 \\
00\end{array}$ \\
\hline 2 & Mahkota & 25.000 & 2 & $\begin{array}{l}\text { Puschasing } \\
\text { pur/bulan }\end{array}$ & $\begin{array}{r}50.00 \\
0\end{array}$ \\
\hline 3 & Adiyan & 82.000 & & & \\
\hline 4 & Cempaka & 52.500 & & & \\
\hline 5 & $\begin{array}{l}\text { Gunawan } \\
\text { design }\end{array}$ & 75.000 & & & \\
\hline 6 & Puspa kencana & 30.000 & & & \\
\hline & Total & 304.50 & & Total & 350.0 \\
\hline & income/month & 0 & & $\begin{array}{l}\text { expenditure/m } \\
\text { onth }\end{array}$ & 00 \\
\hline & & & & $\begin{array}{l}\text { Pay worker/3 } \\
\text { bulan }\end{array}$ & $\begin{array}{r}300.0 \\
00\end{array}$ \\
\hline
\end{tabular}

Source. Authors

Management from the economic

aspect has not running well, because

the income earned less than

expenditure. When there is a damage

to the WWTP, sometimes it can not

be immediately fixed up because

there is no fund.

\section{Management of environmental aspects}

The management of environmental aspects is obtained by measuring the quality of wastewater. The quality of wastewater discharged into the river will affect the quality and the ecosystem of the river (Corominas, 2014:83). In order the wastewater do not give any negative impacts to the environment, the 
results of wastewater treatment should not above the standards of environmental quality. Wastewater samples has been taken at WWTP inlet and WWTP outlet (see Figure 2). 


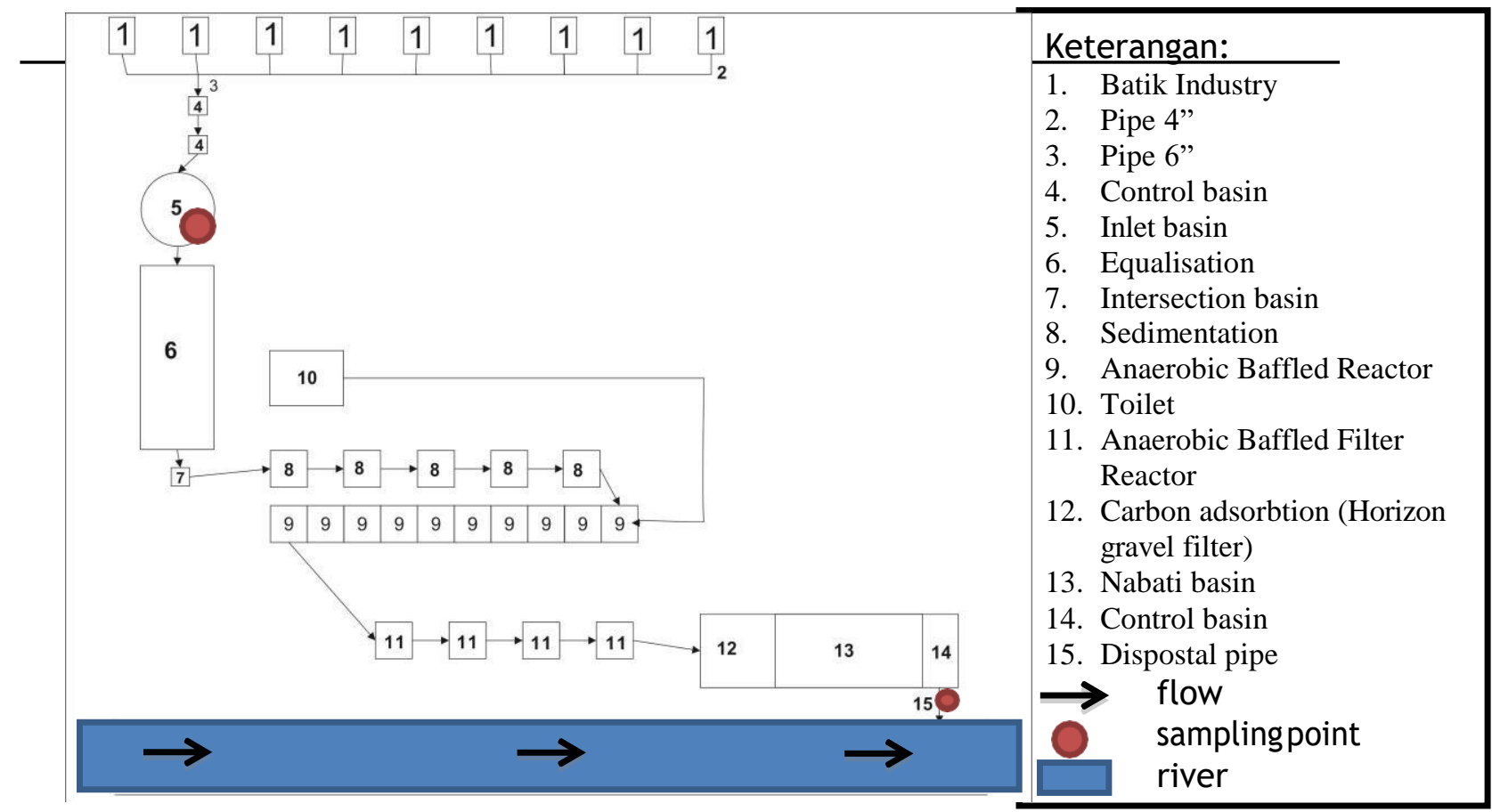

Figure 2. Sampling Point Batik Wastewater Source. Authors

The outlet water quality will be compared with the quality standard of the Central Java Provincial Regulation No. 5 of 2012 on Wastewater Quality Standard for Textile and Batik. After doing the treatment, the quality of wastewater parameters in the WWTP outlet is still above the standard quality, that parameters is sulfides, oils and fats (see Table 2). The value of Oil and fats in inlet $2,4 \mathrm{mg} / \mathrm{L}$ but in outlet the value $4 \mathrm{mg} / \mathrm{L}$. The value of oil and fat should decrease but in outlet increasing. This is happen caused by flokuasi process. Oils and fats derived from the content of the wax. The oil and fats contents are still high because the cleaning processes in equalization basin are not conducted well. the equalization basin must be cleaned every 3 month, but it don't do well. The measurement results showed the sulfide in the inlet $0,449 \mathrm{mg} / \mathrm{L}$. This value is above the quality standards of regulation in Central Java. Sulfide derived from the reform process of organic substances such as hydrogen sulfide $\left(\mathrm{H}_{2} \mathrm{~S}\right)$. This sulphide caused odor in sewage treatment, Therefore, it is not surprisingly if some local people will complain about the odor resulted in this process. 
Table 2

Quality of Wastewater at Inlet and Outlet WWTP in Kampoeng Laweyan

\begin{tabular}{|c|c|c|c|c|c|c|}
\hline $\begin{array}{l}\mathrm{N} \\
\mathrm{O}\end{array}$ & Parameter & $\begin{array}{r}\text { Uni } \\
\mathrm{t}\end{array}$ & $\begin{array}{l}\text { Inle } \\
\mathrm{t}\end{array}$ & $\begin{array}{l}\text { Out } \\
\text { let }\end{array}$ & $\begin{array}{l}\text { Stand } \\
\text { art }\end{array}$ & $\begin{array}{c}\text { Ef } \\
\text { isi } \\
\text { en } \\
\text { si }\end{array}$ \\
\hline 1 & $\begin{array}{l}\text { Temperatur } \\
\mathrm{e}\end{array}$ & ${ }^{0} \mathrm{C}$ & 27 & 28 & 38 & \\
\hline 2 & TSS & $\frac{\mathrm{mg}}{/ \mathrm{L}}$ & 31 & 16 & 50 & $\begin{array}{l}48 \\
\%\end{array}$ \\
\hline 3 & $\mathrm{pH}$ & & $\begin{array}{r}12 \\
26\end{array}$ & $\begin{array}{r}7,0 \\
4\end{array}$ & $6-9$ & $\begin{array}{l}43 \\
\%\end{array}$ \\
\hline 4 & $\mathrm{Cr}(\mathrm{IV})$ & $\underset{/ \mathrm{L}}{\mathrm{mg}}$ & $\begin{array}{r}<0, \\
000 \\
3\end{array}$ & $\begin{array}{l}<0, \\
000 \\
3\end{array}$ & 1 & \\
\hline 5 & Amonia & $\underset{/ L}{\mathrm{mg}}$ & $\begin{array}{r}0,2 \\
94\end{array}$ & $\begin{array}{r}0,0 \\
79\end{array}$ & 8 & $\begin{array}{l}73 \\
\%\end{array}$ \\
\hline 6 & COD & $\frac{\mathrm{mg}}{/ \mathrm{L}}$ & $\begin{array}{r}196 \\
6\end{array}$ & $\begin{array}{r}109 \\
, 5\end{array}$ & 160 & $\begin{array}{r}94 \\
\%\end{array}$ \\
\hline 7 & BOD & $\underset{/ L}{\mathrm{mg}}$ & $\begin{array}{r}110 \\
8\end{array}$ & $\begin{array}{r}39, \\
29\end{array}$ & 60 & $\begin{array}{r}96 \\
\%\end{array}$ \\
\hline 8 & Oil and fat & $\underset{/ L}{\mathrm{mg}}$ & 2,4 & 4 & 3 & $\begin{array}{r}- \\
67 \\
\%\end{array}$ \\
\hline 9 & Sulfida & $\underset{/ \mathrm{Lg}}{\mathrm{mg}}$ & $\begin{array}{r}3,3 \\
63\end{array}$ & $\begin{array}{r}0,4 \\
49\end{array}$ & 0,3 & $\begin{array}{r}87 \\
\%\end{array}$ \\
\hline $\begin{array}{l}1 \\
0\end{array}$ & Phenol & $\frac{\mathrm{mg}}{/ \mathrm{L}}$ & $\begin{array}{r}0,0 \\
54\end{array}$ & $\begin{array}{r}0,0 \\
13\end{array}$ & 0,5 & $\begin{array}{l}76 \\
\%\end{array}$ \\
\hline
\end{tabular}

Source. Authors 


\section{CONCLUSIONS}

Wastewater management
system in Kampoeng Batik batik
Laweyan is less than expected
because not all aspects of the
management run well. The aspects
that have been run well are technical
and managerial aspects. On the other
hand, the aspects that have not run
well are the economic and
environmental aspects. The
economic aspect has not run well
because the received income is less
than the real expenditure. Moreover,
from the environmental aspect, there
are some parameters of the
wastewater are still above the
standard.

\section{ACKNOWLEDGEMENT}

Thanks to School of Environmental Sciences, Universitas Indonesia and parties of Kampoeng Batik Laweyan who have supported and facilitated this paper.

\section{REFERENCES}

Agamuthu, P., Fauziah, S.H., Khidzir, K.M., \& Aiza, N. (2007). Sustainable waste management-asian perspectives. Proceedings of the international conference on sustainable solid waste management (pp. 15-26). India:Chenai.

Alhusain, A.S. (2015). Kendala dan upaya pengembanan industri batik di Surakarta menuju standarisasi. Jakarta:P3DI.

Aspinwall, R. \& Cain, J. (1997). The changing mindset in the management of waste. Philosophical Transactions:Mathematical, Physical and Engineering Sciences, 355, 1425-1437.

Aydiner, C., Sen, U., Koseoglu-Imer, D.Y., Dogan, E.C. (2016). Herarchical prioritization of innovative treatment systems for sustainable dairy wastewater management. Journal of Cleaner Production, 112, 4605-4617.

Al-Kdasi, A., Idris, A., Saed, K., Guan, C.T. (2004). Treatment of textile 
wastewater by advanced oxidation

processes. Global Nest:the

Inernational Journal, 6 , 222-230.

Bratina, B., Sorgo, A., Kramberger, J., Ajdnik, U., Zemlic, L.F., Ekart, J., Safaric, R. (2016). From municipal/industrial wastewater sludge and FOG to fertilizer:proposal for economic sustainable sludge management. Journal of Environmental Management, 183, 1009- 1025.

Corominas, L., Neumann, M.B. (2014). Ecosystem-based management of a Mediterranean urban wastewater system:A sensitivity analysis of the operational degrees of freedom. Journal of Environmental Management, 143, 80-87.

Gray, J. M. (1997). Environment, Policy and Municipal Waste Management in the UK. The Royal Geographical Society:British Geographers.

Helstrom, D., Jeppsson, U., Karrman, E.
(2000). A framework for systems analysis of sustainable urban water management. Environment impact assessment review, 20, 311-321.

Legras, S. (2015). Correlated environmental impacts of wastewater management in a spatial context. Regional Science and Urban Economics, 52, 83-92.

Lu, B., Du, X., Huang, S. (2016). The economic and environmental implications of wastewater management policy in China:From the LCA perspective. Journal of Cleaner Production, xxx, 1-14.

McDougall, F., White, P., Franke, M., Hindle, P. (2007). Integrated Solid Waste Management:A Life Cycle Inventory (2nd edn). United Kindom:Blackwell Publishing.

MetCalf \& Eddy. (1991). Wastewater Engineering :Treatment, Disposal and Reuse. New York:McGraw Hill Book Co. 
Nurdalia, I. (2006). Kajian dan Analisis

Peluang Penerapan Produksi Bersih

Pada Usaha Kecil Batik Cap. Tesis.

Semarang:Program Pascasarjana

UNDIP.

Piao, W., Kim, Y., Kim, H., Kim, M,.

Kim, C. (2015). Life cycle assessment and economic efficiency

Rivera, A.P., Sagastume, J.M.M., Noyola, A., guereca, L.P. (2016). Addressing social aspects associated with wastewater treatment facilities. Environmental Impact Assessment Review, 57, 101-113.

Sun, Y.,Chen, A., Wu, G., Wu, Q., Zhang, F. Niu, Z., Hu, H.Y. (2016).

Characteristics of water quality of municipal wastewater treatment plants in China:implications for resources utilization and management. Journal of Cleaner Production, 131, 1-9.

Tortajada, C. \& Castelan, E. (2003). Water analysis of integrated management of wastewater treatment plants. Journal of cleaner production, 113, 325-337.

Priyatmono,

A.B. (2014).

Monografi

Kampoeng

Batik

Laweyan.

Surakarta:Forum Batik Laweyan

management

dor

a

mehacity:Mexicocity metrapolitan area. Ambio, 32, 124-129.

Tsagarakis, K.P, Mara, D.D., Angelakis, A.N. (2001). Wastewater management in Greece:experience and lessons for developing countries. Water science and technology, 44, 163-170.

WHO. (2000). Tools for assessing the O\&M status of water supply and sanitation in developing countries. Retrieved from ttp://www.sswm.info/library/6459.

Wihastoro, F.P. (2013). Perkembangan dan Pengaruh Keberadaan Industri 
Kampoeng Batik Laweyan Terhadap

\section{Kondisi Perekonomian Wlayah}

Kelurahan Laweyan Kota Surakarta.

Yogyakarta:Fakultas Geografi UGM. 
